\section{High-frequency Direct Somatic Embryogenesis and Plantlet Regeneration from Leaves Derived from In Vitro-Germinated Seedlings of a Coffea arabica Hybrid Cultivar}

\author{
Jane Kahia ${ }^{1}$ \\ World Agroforestry Centre (ICRAF) Cote d' Ivoire Country Program Cocody \\ Mermoz, Abidjan, Côte d'Ivoire 08 BP 2823 ABIDJAN 08
}

Margaret Kirika

Institute of Water and Wetland Research, Radboud University, Heijendaalseweg 135, 6525 AJ Nijmegen, The Netherlands

\author{
Hudson Lubabali \\ Coffee Research Institute P.O. Box 4, Ruiru, Kenya
}

\begin{abstract}
Sinclair Mantell
Nakhlatec International Development Advisors, Abrahamsäng, 37045 Fågelmara, Sweden
\end{abstract}

Additional index words. somatic embryos, juvenile tissues, Coffea arabica, kinetin, TDZ

\begin{abstract}
Breeding work carried out during the period 1971-85 by the Coffee Research Institute, Ruiru, Kenya resulted in the release of a new improved hybrid Coffea arabica named Ruiru 11. The cultivar combines resistance to coffee berry disease (CBD) and leaf rust, with high yield and good cup quality attributes. The propagation by $F_{1}$ hybrid seeds production, cuttings, and tip grafting do not produce enough planting materials. There was a need to explore alternative methods and tissue culture offers potential options. The objective of the study was to evaluate the effect of explant sources and cytokinins on induction and regeneration of somatic embryos. Eight different explants were cultured on half-strength Murashige and Skoog (MS) medium supplemented with $10 \mu \mathrm{M}$ benzylaminopurine (BAP). The effect of kinetin, $\mathrm{N}^{6}$-(2-isopentyl) adenine (2iP) evaluated at $(0,0.5,5$, or $25 \mu \mathrm{M})$ or thidiazuron (TDZ) $(0,0.5,1.0$, or $5 \mu \mathrm{M})$ added in separate experiments was also evaluated. The percentage of embryogenic cultures and the numbers of embryos per explant were determined after 3 months' culture. The explant type had a significant effect $(P>0.05)$ on the induction of somatic embryos. Explants from in vitro-germinated seedlings produced the highest embryogenic cultures $(90 \%)$ and the highest mean number of embryos (19.36) per explant. Cytokinins strongly enhanced induction and regeneration of somatic embryos. TDZ at $1 \mu \mathrm{M}$ produced the highest embryogenic cultures $(100 \%)$ and the highest mean number of embryos (24.2). The embryos were germinated on half-strength MS medium without any hormones. A high $\mathbf{( 9 8 \% )}$ survival rate of the regenerated plantlets was recorded over all the treatments in the greenhouse. This is the first report on induction of high-frequency direct somatic embryos from coffee juvenile tissues. This is of great significance in tissue culture and indeed molecular biology manipulations because it allows regeneration of coffee from several explants.
\end{abstract}

Coffee is an economically important crop grown in $\approx 80$ countries across the world (Los Santos-Brones and Hernandez-Sotomayor, 2006). The genus Coffee comprises $\approx 100$ species of which only two species, Arabica coffee and Robusta coffee, are commercially cultivated (Los Santos-Brones and Hernandez-Sotomayor,

Received for publication 15 Mar. 2016. Accepted for publication 24 May 2016.

We wish to acknowledge and thank Prof Esther Kahangi of the Jomo Kenyatta University of Agriculture and Technology for her contributions to this article.

${ }^{1}$ Corresponding author. E-mail: j.kahia@cgiar.org.
2006). Disease control is one of the major constraints to sustainable and economic coffee production (Gichuru et al., 2012). Breeding work in Kenya has resulted in the release of a new improved cultivar-Ruiru 11. Moreover, the hybrid combines resistance to CBD and leaf rust with high yield and good cup quality attributes (Van der Vossen and Walyaro, 1980). The development and dissemination of Ruiru 11 has made a significant contribution not only to the coffee farmers, but also to the Kenyan community as a whole for the following reasons:

- Its availability and use has the potential to reduce the cost of coffee production by up to $30 \%$ and thereby saves the Kenyan government considerable amounts of foreign currency usually spent on the importation of fungicides and spraying equipment.

- Its use will increase and stabilize the incomes of small-scale farmers for whom disease control using chemicals is frequently impossible to realize.

- Most importantly it offers potential environmentally friendly approach to the long-term control of coffee diseases and in production of organically grown coffee.

The propagation of Ruiru 11 is by $F_{1}$ hybrid seed, production through hand artificial cross-pollination (Van der Vossen and Walyaro, 1981), cuttings, and tip grafting (Wamatu and Kingoro, 1991). The number of planting materials produced by the above methods is far below those needed to supply farmer's demand. Therefore, there is need to accelerate the production of Ruiru11 planting materials by using alternative methods such as tissue culture.

A great deal of work has been carried out on coffee somatic embryogenesis using the indirect method. However, direct somatic embryogenesis (DSE) has not received much attention. This is although DSE is preferred, as it has the potential for maintaining genomic stability of regenerated plants. The former method that is via an intermediate callus phase increases the possibility of somaclonal variations (Tang and Guo, 2001).

Of the several factors that influence the process of somatic embryogenesis, the most important are the origin of the explant and composition of the culture medium, particularly with respect to the type and concentration of growth regulators. Somatic embryogenesis is known to be highly dependent on the explant used. The kind of explant chosen, its size, age, and the manner in which it is placed on the media can all determine whether morphogenesis can be induced (Rossin and Rey, 2011). Explants taken from juvenile plant tissues, particularly those from seedlings, are usually highly responsive. For example, while working on somatic embryogenesis of chickpea, Rao (1991) observed that more embryos were produced from leaf explants of 9-d-old seedlings than from older explants. In general, explants from newly originating organs are known to be more responsive than those taken from older ones (George, 1993). In vitro plant-derived leaves are regarded as rejuvenated plant materials (Nozeran, 1978) in which the endogenous hormonal balance is probably different from that of physiologically older leaves from glasshouse or field-grown plants. The embryogenic potential of this type of explant is considered to be substantially higher than the glasshouse and field-grown explants (Franclet, 1983). Micropropagated leaf explants from C. arabica and Anthurium scherzarium plants were found to be better explants than all the others tested (Bieysse et al., 1993; Hamida et al., 1997).

Most researchers working on coffee somatic embryogenesis have used leaves from the field or glasshouse plants as source of 
explant (Boxtel and Berthouly, 1996; De Almeida et al., 2014; Tahara et al., 1994). The production of embryos and plantlets from leaf explants offers a number of advantages including, uniform leaf material, and abundantly available and easily renewable source of explants.

Growth in vitro is highly dependent on the interaction between naturally occurring endogenous growth substances and the analogous synthetic growth regulators that may be added to the medium (George, 1993). The induction of DSE in C. arabica is strongly associated with the addition of cytokinins to the culture medium, in the absence of auxins (Almeida and Silvarolla, 2009; De Almeida et al., 2014; Kahia, 1999). The objective of the current study was to evaluate the ideal explant and the best type and concentration of cytokinins (phenylurea-type vs. adenine-type) for induction and regeneration of direct somatic embryos in the new cultivar.

\section{Materials and Methods}

\section{Experimental site characteristics}

The study was undertaken at the Coffee Research Station (CRS) in Ruiru, Kenya. The CRS is located on lat. $1^{\circ} 06^{\prime} \mathrm{S}$ long. $36^{\circ} 45^{\prime} \mathrm{E}$ and an altitude of $1608 \mathrm{~m}$ above sea level.

\section{Plant materials}

The explants evaluated were type 1 ; leaves from in vitro-germinated seedlings, type 2 ; leaves from 6-month-old seedlings raised in green house, type 3; hypocotyls of somatic embryos type 4; leaves from coffee somatic embryos, type 5; lateral roots of coffee somatic embryos, type 6; primary roots of somatic embryos, type 7; cotyledonary leaves of embryos, and type 8; leaves from field-grown trees.

Third pair of leaves was harvested from 6-month-old seedlings growing in the greenhouse and field-grown coffee plants. They were taken to the laboratory in polythene bags and kept under running tap water for $30 \mathrm{~min}$. This was followed by sterilization using 20\% commercial bleach (JIK) which contains $3.85 \%(\mathrm{w} / \mathrm{v})$ sodium hypochlorite for $15 \mathrm{~min}$ and rinsing twice in sterile distilled water and thereafter a quick immersion (30 s) in $70 \%(\mathrm{v} / \mathrm{v})$ ethanol and finally rinsing four times in sterile distilled water. The other explants used were in vitro derived and there was no need to surface sterilize them as they were presumed to be clean. The leaf explants used were $\approx 1 \mathrm{~cm}^{2}$ in size (excluding the main vein, edges, and apical and basal portions) and the other explants were $\approx 5 \mathrm{~mm}$ in length

The media used to evaluate the effect of explant source on induction and regeneration of somatic embryos was half-strength MS (1962) supplemented with $10 \mu \mathrm{M}$ BAP, $100 \mathrm{mg} / \mathrm{L}$ inositol, $30 \mathrm{mg} / \mathrm{L}$ cysteine- $\mathrm{HCl}$, and 3\% (w/v) sucrose and gelled with $0.3 \%$ Phytagel.

Leaves from in vitro-germinated seedlings were cultured on half-strength MS media supplemented with $30 \mathrm{mg} / \mathrm{L}$ cysteine, $100 \mathrm{mg} / \mathrm{L}$ inositol, and 3\% (w/v) sucrose. To this media, adenine type of cytokinins (kinetin or $2 \mathrm{iP}$ ) tested at three concentrations and a control $(0,0.5,5$, or $25 \mu \mathrm{M})$ and phenylurea type cytokinin (TDZ) tested at $0,0.5,1$, or $5 \mu \mathrm{M}$ were added in separate experiments.

The media $\mathrm{pH}$ was adjusted to 5.8 by using either $1 \mathrm{~N} \mathrm{HCL}$ or $1 \mathrm{~N} \mathrm{NaOH}$ before the gelling agent was added. The media was dispensed in culture vessels and autoclaved at a temperature of $121{ }^{\circ} \mathrm{C}$ and a pressure of $1.1 \mathrm{~kg} \cdot \mathrm{cm}^{-2}$ for $20 \mathrm{~min}$. The cultures were incubated in a dark room maintained at $25 \pm 2{ }^{\circ} \mathrm{C}$. The explants were induced for $14 \mathrm{~d}$ on the above medium and then transferred to the medium without growth regulators. The regenerated embryos were germinated in a growth room maintained at $25 \pm 2{ }^{\circ} \mathrm{C}$, cool white fluorescent light intensity of $33 \mu \mathrm{mol} \cdot \mathrm{m}^{-2} \cdot \mathrm{s}^{-1}$, and $16-\mathrm{h}$ photoperiod.

All experiments were laid out in completely randomized design with 20 replicates per treatment and the experiment repeated three times. The data were subjected to oneway analysis of variance and the significant differences between treatment means were assessed by using Minitab version 14 Software. The percentage of embryogenic cultures was calculated by the number of cultures that produced embryos (any stage between globular and early cotyledonary stage) divided by the total number of cultures multiplied by 100 . Counting of embryos was done using a binocular microscope (at magnification $\times 10-20$ ). Cultures were monitored on a weekly basis for contamination. The assessment of the percentage of embryogenic cultures and the numbers of embryos per explant were carried out after 3 months. The results are expressed as a mean \pm SE. The total number of embryos was the combined summation of somatic embryos at different stages (as described below) of development in each culture.

Globular stage. Discrete round structures with no visible cotyledons or apical dome originating and projecting above the explant.

Heart-torpedo stage. Intermediate between globular and cotyledonary stages, having a heart shape formed by developing cotyledons.

Early and late cotyledonary stage. Variable in size, but possessing differentiated cotyledons.

\section{Acclimatization}

The plantlets were removed from the test tubes and the roots gently cleaned with running tap water to remove the culture media. A total of 100 plants were then taken to the glasshouse where they were treated with $2 \%$ fungicide (Redomil for $10 \mathrm{~min}$ ). The plantlets were sown in pots (supplied by Sunplam Australia) containing substrate composed of top soil, river sand, and cattle manure mixed in the ratio of $3: 2: 1(\mathrm{w} / \mathrm{w})$. The holes on the covers were closed for 2 weeks to build the relative humidity. They were then gradually opened for another 2 weeks to reduce the humidity and eventually fully opened after 1 month. The plants were watered weekly with tap water using a hand operated sprayer.

\section{Results}

Effect of explant source on induction of somatic embryos. The explant type had a significant effect $(P<0.05)$ on the induction of somatic embryos in Ruiru 11. Embryos were induced from all of the explants tested. Embryogenic initials were first observed from in vitro-germinated seedlings leaf explants after 2 weeks of culture. In the case of other explants tested, embryogenic initials were observed after 3-4 weeks culture. Explants from in vitro-germinated seedlings produced the highest frequency $(90 \%)$ of embryogenic cultures (Fig. 1A) and the highest mean numbers of embryos (19.3) per explant (Fig. 1B), whereas explants from cotyledonary leaves produced the lowest (3.64) mean numbers of embryos per explant. Somatic embryos were observed from the cut edges of all types of explants tested and frequently, the various developmental stages of somatic embryos (globular, heart, torpedo, and cotyledonary stages) were observed in the same culture (Fig. 2A). In vitro-regenerated coffee plantlets with well-developed roots (Fig. 2B).

Effect of cytokinin type and concentration on induction of somatic embryos. The presence of cytokinins strongly enhanced the induction and regeneration of somatic embryos in the new hybrid. Initiation of somatic embryos was first observed after 2 weeks on medium supplemented with $5 \mu \mathrm{M} 2 \mathrm{iP}$ and $1 \mu \mathrm{M}$ TDZ. The presence of $2 \mathrm{iP}$ in the medium had a significant effect $(P<0.05)$ on induction and regeneration of somatic embryos in Ruiru 11. Increasing the concentration of $2 \mathrm{iP}$ from 0.5 to $5 \mu \mathrm{M}$ significantly increased both the frequency and the number of embryos, while raising the concentration beyond $5 \mu \mathrm{M}$ resulted in a decrease in the frequency and mean number of embryos. $2 \mathrm{iP}$ at $5 \mu \mathrm{M}$ produced the highest (22.4) mean numbers of embryos per explant (Table 1).

Supplementing the medium with kinetin had a significant effect $(P<0.05)$ on the mean numbers of embryos per explant. Kinetin at $5 \mu \mathrm{M}$ gave the highest (14.3) mean number of embryos (Table 2). On the other hand, TDZ at $1 \mu \mathrm{M}$ produced the highest frequency $(100 \%)$ of embryogenic cultures and the highest (24.2) mean number (Table 3 ).

Acclimatization. The regenerated plantlets were weaned by gradually reducing the relative humidity in the pots and finally exposing them to the external environment (Fig. 3A). A survival rate of $98 \%$ was recorded in the greenhouse (Fig. 3B)

\section{Discussion}

The explants source is an important factor affecting the in vitro propagation of many plant species. Somatic embryogenesis in the new hybrid appeared to be strongly explant dependent. Leaves from in vitro-germinated seedlings were found to be the best source of explant. The results of this study concur with those of Siong et al. (2011) who found that cauliflower juvenile leaf explants formed significantly more embryos than the hypocotyl explants. The root explants gave wellsynchronized embryos. Unfortunately, the embryos obtained from root explants became contaminated in the 2nd month of culture. The reason for this was unclear, but it is likely 

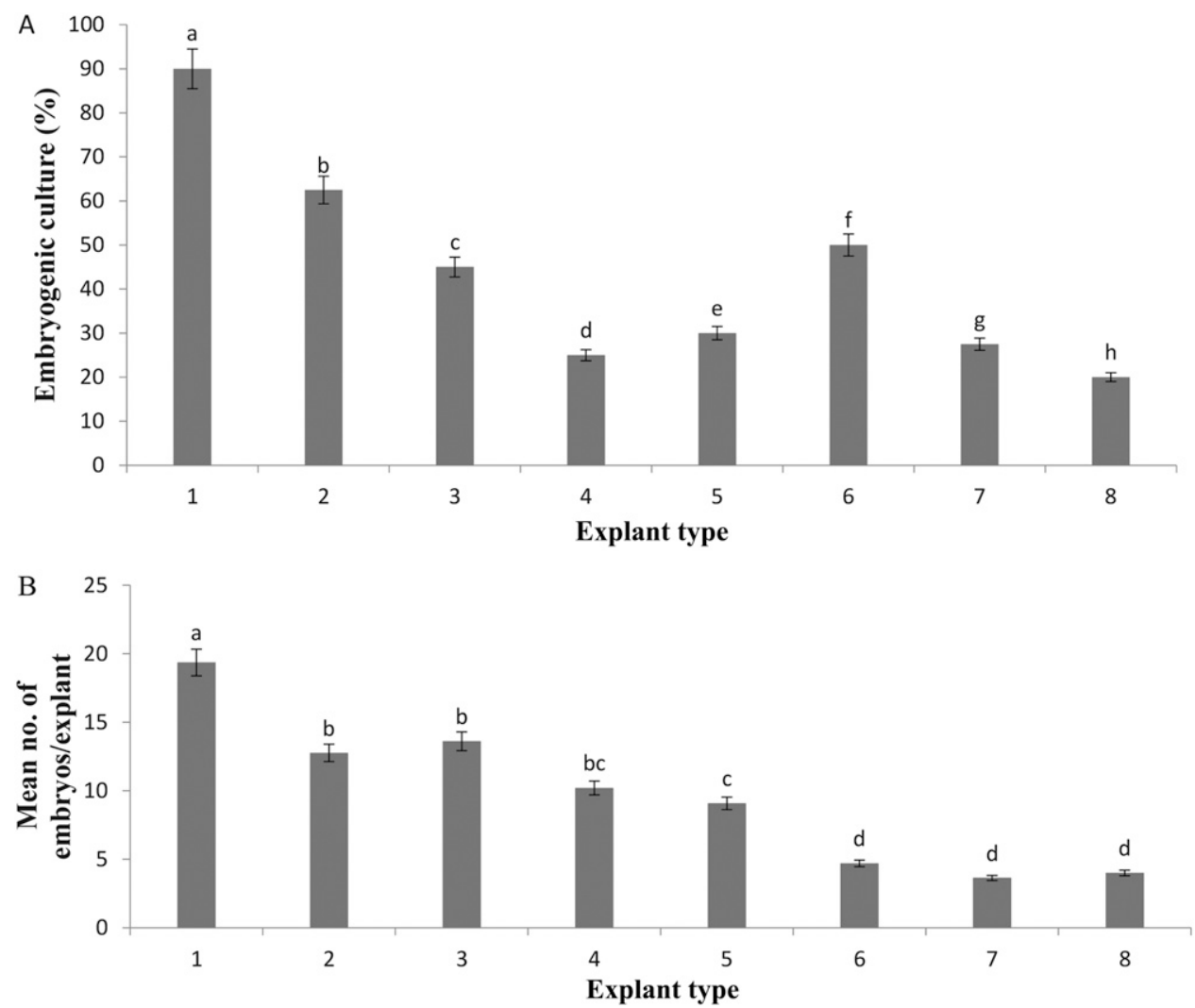

Fig. 1. Effect of different explants types on induction and regeneration of somatic embryos. (A) The frequency of somatic embryo regeneration. (B) The mean number of embryos. 1, Leaves from in vitro-germinated seedlings; 2, leaves from 6-month-old seedlings; 3, hypocotyls of embryo 4, leaves from in vitro-propagated somatic embryos; 5 , lateral roots of somatic embryos; 6 , primary roots of embryos; 7 , cotyledonary leaves of embryos; and 8 , leaves from field-grown trees.
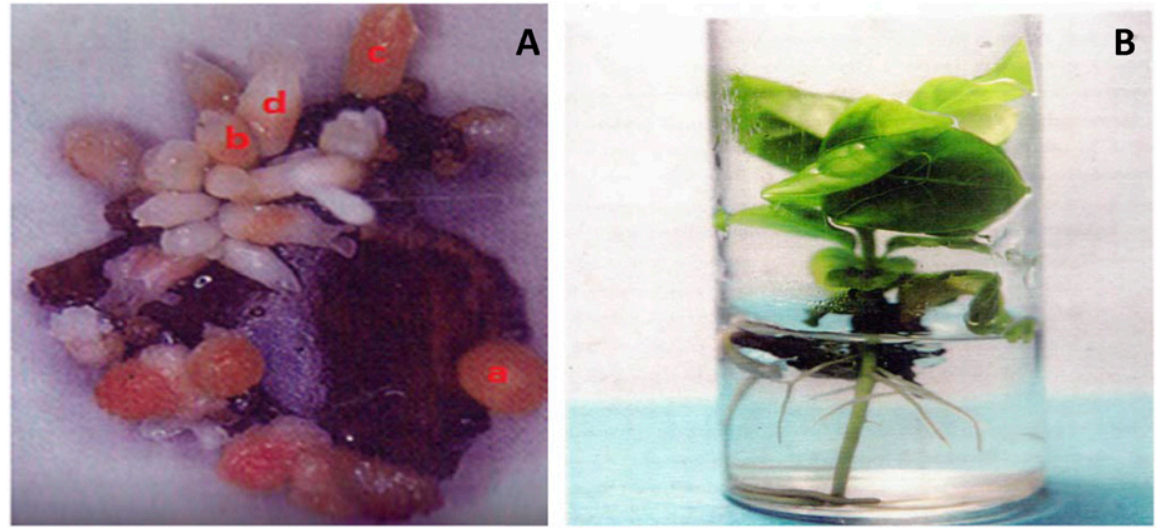

Fig. 2. (A) Different stages of coffee somatic embryos derived from the media supplemented with thidiazuron $1 \mu \mathrm{M}$. (a) Globular, (b) heart-shaped, (c) torpedo, and (d) early cotyledonary stage in a single culture after $90 \mathrm{~d}$ in culture. (B) Plantlet with well-developed shoot and root ready for weaning.

to have been caused by random coincidental infection or as a result of endophytic microbes associated with this particular type of tissue. According to the International Coffee Organization report (ICO, 1986), somatic embryogenesis in coffee has been achieved from various explants except root explant. The results of the current study are the first report on induction of somatic embryos from root explants in coffee. The different responses of the explant types under the same media regime are probably due to the endogenous hormonal balance in plant tissues (Grattapaglia and
Machado, 1998). These differences in various explants can be explained by changes in the levels of endogenous hormones and the expression of genes encoding hormone receptors, as proposed by Gallagher-Ludeman and Close (1989).

The role of cytokinin on somatic embryogenesis has been explained by enhanced cell division of preembryogenically determined cells (Kintzios et al., 2002). The cytokinins tested during the current study had a significant effect on induction of somatic embryos of Ruiru 11. The responses were influenced not only by the type of cytokinin but also their concentrations. Although $2 \mathrm{iP}$ is not very often used in tissue culture, exogenous $2 \mathrm{iP}$ has shown beneficial effect on somatic embryogenesis for some plants (Capelo et al., 2010; Comlekcioglu et al., 2009; Khierallah et al., 2015). Kinetin was found to be inferior to the other cytokinins tested. These results contradict with those of Ramos et al. 2009, who found kinetin better than other cytokinins tested in somatic embryogenesis of coffee. This could be due to the difference in the genetic makeup. TDZ at $1 \mu \mathrm{M}$ produced $100 \%$ embryogenic cultures and the highest mean numbers of embryos. These results are consistent with those of Gill and Saxena (1993) who reported $100 \%$ induction of somatic embryos on Nicotiana tabacum leaf explants using TDZ. TDZ is chiefly used as cotton defoliant (Giridhar et al., 2004), but it also acts as a growth regulator in tissue culture systems. It has been shown to stimulate somatic embryogenesis in woody species such as white ash (Bates et al., 1992), eastern black walnut (Neuman et al., 1993), apples (Daigny et al., 1996), and cacao ( $\mathrm{Li}$ et al., 1998). In peanut and geranium, the use of TDZ has effectively replaced the requirement of auxin and/or cytokinin for inducing somatic embryogenesis (Gill and Saxena, 1992; Visser et al., 1992). During the current study, the frequency and number of somatic embryos per explant was found to gradually decline with increasing concentration of TDZ beyond the optimum. It is 
likely that TDZ results in a balanced ratio of endogenous growth regulators that allows for specific mode of regeneration to take place and this is likely to be dependent on the

Table 1. Effects of $2 \mathrm{iP}$ on induction and regeneration of somatic embryos.

\begin{tabular}{lcc}
\hline $\begin{array}{l}\text { 2iP concn } \\
\text { in }(\mu \mathrm{M})\end{array}$ & $\begin{array}{c}\text { Embryogenic } \\
\text { cultures }(\%)\end{array}$ & $\begin{array}{c}\text { Mean no. of } \\
\text { embryos/explant }( \pm \mathrm{SE})\end{array}$ \\
\hline 0 & 0 & $0^{\mathrm{z}}$ \\
0.5 & 38 & $11.5 \pm 0.54 \mathrm{a}$ \\
5 & 93 & $22.4 \pm 0.71 \mathrm{~b}$ \\
25 & 58 & $11.7 \pm 0.71 \mathrm{a}$ \\
\hline
\end{tabular}

$2 \mathrm{iP}=\mathrm{N}^{6}$-(2-isopentyl) adenine.

Values represent means \pm SE (40 replicates). Means within a column followed by different letters are significantly different at $P<0.05$.

${ }^{2}$ The zero response were not included in the statistical analysis.

Table 2. Effects of kinetin on induction and regeneration of somatic embryos.

\begin{tabular}{lcc}
\hline $\begin{array}{l}\text { Kinetin concn } \\
\text { in }(\mu \mathrm{M})\end{array}$ & $\begin{array}{c}\text { Embryogenic } \\
\text { cultures }(\%)\end{array}$ & $\begin{array}{c}\text { Mean no. of } \\
\text { embryos/explant } \\
( \pm \mathrm{SE})\end{array}$ \\
\hline 0 & 0 & $0^{\mathrm{z}}$ \\
0.5 & 10 & $2.3 \pm 0.63 \mathrm{a}$ \\
5 & 53 & $14.3 \pm 0.49 \mathrm{~b}$ \\
25 & 73 & $12.6 \pm 0.52 \mathrm{~b}$ \\
\hline
\end{tabular}

Values represent means \pm SE (40 replicates). Means within a column followed by different letters are significantly different at $P<0.05$.

${ }^{2}$ The zero responses were not included in the statistical analysis.

Table 3. Effects of TDZ on induction and regeneration of somatic embryos.

\begin{tabular}{lcc}
\hline $\begin{array}{l}\text { TDZ concn } \\
\text { in }(\mu \mathrm{M})\end{array}$ & $\begin{array}{c}\text { Embryogenic } \\
\text { cultures }(\%)\end{array}$ & $\begin{array}{c}\text { Mean no. of } \\
\text { embryos/explant }( \pm \mathrm{SE})\end{array}$ \\
\hline 0 & 0 & $0^{\mathrm{z}}$ \\
0.5 & 75 & $14.2 \pm 0.43 \mathrm{a}$ \\
1 & 100 & $24.2 \pm 0.40 \mathrm{~b}$ \\
5 & 78 & $14.3 \pm 1.34 \mathrm{a}$ \\
\hline
\end{tabular}

TDZ $=$ Thidiazuron.

Values represent means \pm SE (40 replicates). Means within a column followed by different letters are significantly different at $P<0.05$.

${ }^{z}$ The zero responses were not included in the statistical analysis.
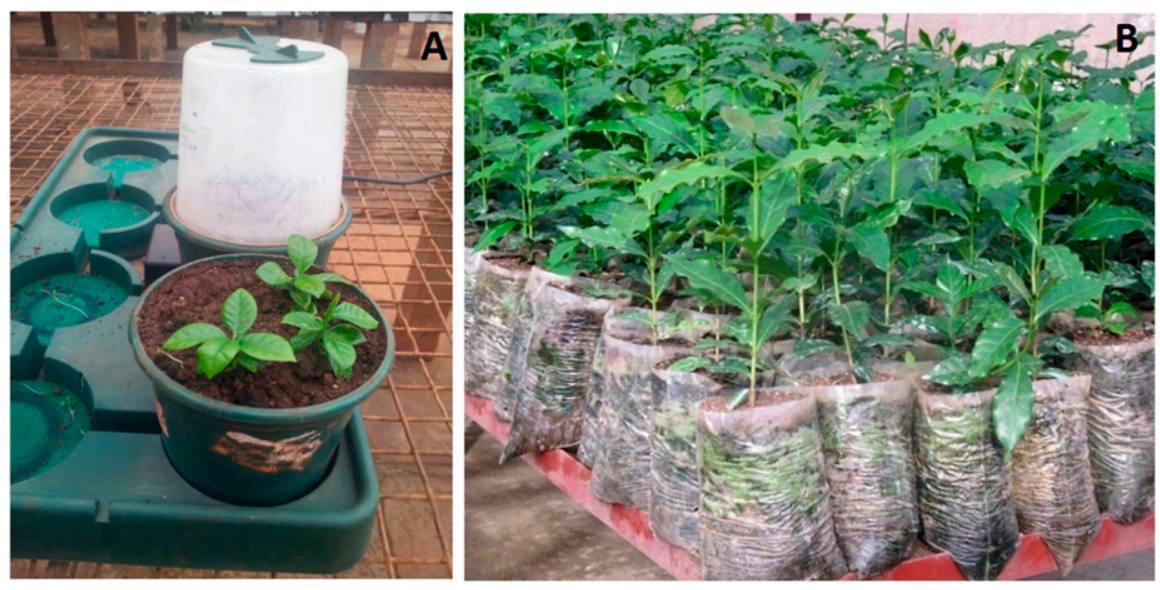

Fig. 3. In vitro-propagated coffee plants in the greenhouse. (A) Weaning of coffee plantlets. (B) Coffee plantlet ready for planting in the field. concentration of TDZ provided in the medium and the species (Anushi et al., 2014). The results of the present study concur with previous work by Khan et al. (2006), Aboshama (2011) who found similar results while working on pepper, and Hua and Chen (2014) while working on Phalaenopsis aphrodite. The reason why such comparative low levels of TDZ are effective on some woody plant tissues, whereas adenine types are not, could be because TDZ is resistant to cytokinindegrading enzymes (oxidases). It is also stable and biologically active at lower concentrations than the adenine type of cytokinins (Mok et al., 1987). Improved regeneration using the urea-based cytokinin TDZ, rather than adenine-based cytokinins, is well documented in different plant species (Bacchetta et al., 2003; Dai et al., 2007; Faisal et al., 2005; Mithila et al., 2003; Sanikhani et al., 2006). There are now many publications on different aspects of the effect of TDZ on plant regeneration. One reason for great level of interest in TDZ could be due to its unique mode of action which may involve, at least in part, the modulation of the levels of endogenous growth regulators, polar auxin transport, and accumulation of proline in TDZ-induced tissues (Murthy et al., 1998). According to Faisal et al. (2005), TDZ is an alternative for high-frequency direct regeneration of somatic embryos in many plants. The effectiveness of TDZ is possibly due to its capacity to stimulate endogenous cytokinin biosynthesis that alters endogenous cytokinin metabolism. These attributes make TDZ possesses a strong cytokininlike activity exceeding the other commonly used adenine-type cytokinins including BAP and kinetin (Li et al., 1998). Another possible explanation according to Hare and Van Staden (1994) could be that TDZ has a capacity to inhibit (at least partially) the action of cytokinin oxidase, which in turn may increase the level of endogenous.

\section{Conclusion}

A relatively simple, straightforward and reproducible method for regeneration of
Coffea arabica-robusta $\times$ canephora var. Ruiru 11 was developed by comparing the direct somatic embryogenesis potentials of several different types of leaf and root explants derived from in vitro raised seedlings exposed to a range of different urea- and adenine-type cytokinins. The cytokin TDZ proved to be the best cytokinin for induction of DSE in this coffee variety. The developed protocol will improve the prospects for large scale production of $F_{1}$ hybrid seed of this variety to supplement existing conventional systems of seed production for this important new coffee variety.

\section{Literature Cited}

Aboshama, H.M.S. 2011. Direct somatic embryogenesis of pepper (Capsicum annuиm L.). World J. Agr. Sci 7(6):755-762.

Almeida, J.A.S. and M.B. Silvarolla. 2009. Induction of somatic embryos of Coffea arabica genotypes by 6-benzyladenine. Intl. J. of Plant Dev. Biol 3:5-9.

Anushi, A.J., M. Anis, and I.M. Aref. 2014 Relative examination of antioxidative enzymatic activities in plantlets of Cardiospermum halicacabum L. differentiated from hypocotyls in in vivo and ex vitro environment. Biotechnol. Rpt. (Amst.) 4:66-72.

Bacchetta, L., P.C. Remotti, C. Bernardini, and F. Saccardo. 2003. Adventitious shoot regeneration from leaf explants and stem nodes of Lilium. Plant Cell Tissue Organ Cult. 74:37-44.

Bates, S., J.E. Preece, N.E. Navarrete, J.W. Van Sambeek, and G.R. Gaffney. 1992. Thidiazuron stimulates shoot organogenesis and somatic embryogenesis in white ash (Fraxinus americana L.). Plant Cell Tissue Organ Cult. 31:21-29.

Bieysse, D., A. Gofflot, and N. Michaux-Ferriere. 1993. Effect of experimental conditions and genotypic variability on somatic embryogenesis of Coffea arabica. Can. J. Bot. 71:1496-1502.

Boxtel, J.V. and M. Berthouly. 1996. High frequency somatic embryogenesis from coffee leaves. Factors influencing embryogenesis and subsequent proliferation and regeneration in liquid medium. Plant Cell Tissue Organ Cult. 44:7-17.

Capelo, A.M., S. Silva, G. Brito, and C. Santos. 2010. Somatic embryogenesis induction in leaves and petioles of a mature wild olive. Plant Cell Tissue Organ Cult. 103:237-242.

Comlekcioglu, N., Y.Y. Mendi, S. Eldogan, and C. Unek. 2009. Effects of different combinations and concentrations of growth regulators and photoperiod on somatic embryogenesis of cucumis melo var. flexuosus. Afr. J. Biotechnol. 8(22):6228-6232.

Dai, H., Z. Zhang, and X. Guo. 2007. Adventitious bud regeneration from leaf and cotyledon explants of Chinese hawthorn (Crataegus pinnatifida Bge. var. major N.E.Br.). In Vitro Cell Dev. Biol. Plant. 43:2-8.

Daigny, G., H. Paul, R.S. Sangwan, and B.S Sangwan-Norreel. 1996. Factors influencing secondary somatic embryogenesis in Malus $\times$ domestica Borkh. (cv'Gloster 69'). Plant Cell Rpt. 16(3-4):153-157.

De Almeida, J.A.S., R.R. Leal, V.C.B. Carmazini, M.V. Salomon, and O. Guerreiro Filho. 2014. Effect of temperature and cytokinin on the capacity of direct somatic embryogenesis in Coffea arabica L. genotypes. Coffee Sci. 9(3):394-399.

Faisal, M., N. Ahmad, and M. Anis. 2005. Shoot multiplication in Rauvolfia tetraphylla $\mathrm{L}$. using thidiazuron. Plant Cell Tissue Organ Cult. 80 : 187-190. 
Franclet, A. 1983. Rajeunissement et micropropagation des ligneux. Ann Assoc. For Cellul. 55-62.

Gallagher-Ludeman, L.A. and K.R. Close. 1989. Structure-activity relationships of auxin-like plant growth regulators and genetic influences on the culture induction responses in maize (Zea mays L). Plant Sci. 61:245-252.

George, E.F. 1993. Plant propagation by tissue culture. Part 1: The technology. 2nd ed. Exegetics Ltd, UK.

Gichuru, E.K., J.M. Ithiru, M.C. Silva, A.P Pereira, and V.M. Varzea. 2012. Additional physiological races of coffee leaf rust (Hemileia vastatrix) identified in Kenya. Trop. Plant Pathol. 37(6):424-427.

Gill, R. and P.K. Saxena. 1992. Direct somatic embryogenesis and regeneration of plants from seedlings explant of peanut (Arachis hypogaea L.): Promotive role of thidiazuron. Can. J. Bot. 70:1186-1192.

Gill, R. and P.K. Saxena. 1993. Somatic embryogenesis in Nicotiana tabacum L. induction by thidiazuron and direct embryo differentiation from leaf discs. Plant Cell Rpt. 12:154-159.

Giridhar, P.A., V.I. Kumar, E.P. Indu, A. Chandrasekar, and G.A. Ravishankar. 2004. Thidiazuron induced somatic embryogenesis in Coffea arabica L. and Coffea Canephora. P Ex Fr. Act. Bot. Croat. 63:25-33.

Grattapaglia, D. and M.A. Machado. 1998. Micropropagation, p. 183-247. In: A.C. Torres, L.S. Caldas, and J.A. Buso (eds.). Cultura de Tecidos e Transformacao Genetica de Plantas. Embrapa-CNPH, Brasilia, Brazil.

Hamida, M., A.G.A. Karim, and P. Debergh. 1997. Somatic embryogenesis and plan regeneration in Anthurium scherzerianum. Plant Cell Tissue Organ Cult. 48:189-193.

Hare, P.D. and J. Van Staden. 1994. Inhibitory effect of thidiazuron on the activity of cytokinin oxidase isolated from soybean callus. Plant Cell Physiol. 35:1121-1125.

Hua, J.F. and J.T. Chen. 2014. A Novel in vitro protocol for inducing direct somatic embryogenesis in Phalaenopsis aphrodite without taking explants. The Sci. World J. 2014:263642.

International Coffee Organization (ICO). 1986. Coffee biotechnol. P. A. Technology, London. p. 1-27.

Kahia, W.J. 1999. In vitro propagation of the disease resistant cultivar-Ruiru 11. PhD Diss., University of London, UK.
Khan, H., I. Siddique, and M. Anis. 2006. Thidiazuron induced somatic embryogenesis and plant regeneration in Capsicum annuum. Biol. Plant. 50(4):789-792.

Khierallah, H.S.M., M.H.S. AlHamdany, A. Abdulkareem, and F.F. Saleh. 2015. Influence of sucrose and pacloburtazol on callus growth and somatic embryogenesis in date palm cv. bream. Intl. J. Current Res. Academic Rev. 3:270-276.

Kintzios, S., E. Sereti, P. Bluchos, J. Drossopoulos, C. Kitsaki, and A. Liopa-Tsakalidis. 2002. Growth regulator pretreatment improves somatic embryogenesis from leaves of squash (Cucurbita pepo L.) and melon (Cucumis melo L.). Plant Cell Rpt. 21:1-8.

Li, Z., J. Traore, A.S. Maximova, and M.J. Guiltinan. 1998. Somatic embryogenesis and plant regeneration from floral explants of cacao (theobroma cacao L.) using thidiazuron. In vitro Cell Dev. Biol. Plant. 34:293299.

Los Santos-Brones, D. and S.M.T. HernandezSotomayor. 2006. Coffee biotechnology. Braz. J. Plant Physiol. 18:217.

Mithila, J., J. Hall, J.M.R. Victor, and P.K. Saxena. 2003. Thidiazuron induces shoot organogenesis at low concentrations and somatic embryogenesis at high concentrations on leaf and petiole explants of African violet (Saintpaulia ionantha Wendl.). Plant Cell Rpt. 21(5):408414.

Mok, C.M., W.S.D. Mok, J.E. Turner, and C.V. Mujer. 1987. Biological and biochemical effects of cytokinins-active phenylurea derivatives in tissue culture systems. J. Hort. Sci. 22:1194-1197.

Murashige, T. and F. Skoog. 1962. A revised medium for rapid growth and bio-assays with tobacco tissue cultures. Physiol. Plant. 15:473497.

Murthy, B.N.S., S.J. Murch, and P.K. Saxena. 1998. Thidiazuron: A potent regulator of in vitro plant morphogenesis. In Vitro Cell. Dev. Biol. Plant 34(4):267-275.

Neuman, M.C., J.E. Preece, J.W. Van Sambeek, and G.R. Gaffney. 1993. Somatic Embryogenesis and callus production from cotyledon explants of Eastern black walnut. Plant Cell Tissue Organ Cult. 32:9-18.

Nozeran, R. 1978. Polymorphisme des individus issus de la multiplication vegetative des vegetaux inferieurs avec conservation du potentiel genetique. Physiol. Veg. 16:177-194.

Ramos, R.A., T. Wondyifraw, F. Martínez, M.E. Gonzalez, G. Endale, T. Alemayehu, and A. Zerihun. 2009. Plant regeneration through somatic embryogenesis in three Ethiopian Coffea arabica Lin. hybrids. Biotecnología Vegetal. 9:19-26.

Rao, B.G. 1991. Influence of explant and its stage of development on response for somatic embryogenesis in chickpea. Adv. Plant Sci. $4: 43-47$.

Rossin, C.B. and M.E.C. Rey. 2011. Effect of explant source and auxins on somatic embryogenesis of selected cassava (Manihot esculenta Crantz) cultivars. S. Afr. J. Bot. 77:59-65.

Sanikhani, M., S. Frello, and M. Serek. 2006. TDZ induces shoot regeneration in various Kalanchoe blossfeldiana Poelln. Cultivars in the absence of auxin. Plant Cell Tissue Organ Cult. 85:72-82.

Siong, P., R. Taha, and F. Rahiman. 2011. Somatic embryogenesis and plant regeneration from hypocotyl and leaf explants of Brassica oleracea var. botrytis (cauliflower). Acta Biol. Cracov. Ser. Bot. 53:26-31.

Tahara, M., T. Yasuda, N. Uchida, and T. Yamaguchi. 1994. Formation of somatic embryos from protoplast of Coffea arabica L. J. Hort. Sci. 29:172-174.

Tang, W. and Z. Guo. 2001. In vitro propagation of loblolly pine via direct somatic organogenesis from mature cotyledons and hypocotyls. Plant Growth Regulat. 33:25-31.

Van der Vossen, H.A.M. and D.J. Walyaro. 1980. Breeding for resistance to coffee berry disease in Coffea arbica L. II. Inheritance of the resistance. Euphytica 29(3):777-791.

Van der Vossen, H.A.M. and D.J. Walyaro. 1981. The coffee breeding programme in Kenya: A review of progress made since 1971 and plan of action for the coming years. Kenya coffee 46 (541):113-130.

Visser, C., J.A. Qureshi, R. Gill, and P.K. Saxena. 1992. Morphoregulatory role of thidiazuron: Substitution of auxin and cytokinins requirement for the induction of somatic embryogenesis in geranium hypocotyl cultures. Plant Physiol. 99:1704-1707.

Wamatu, J.N. and M.W. Kingoro. 1991. Vegetative propagation of Ruiru 11 by rooting softwood stem cuttings. Kenya Coffee 57:1399-1404. 